UDK $577.1: 61$

ISSN 1452-8258

\title{
THE IMPACT OF OBESITY TO ANTIOXIDANT DEFENSE PARAMETERS IN ADOLESCENTS WITH INCREASED CARDIOVASCULAR RISK
}

\author{
UTICAJ GOJAZNOSTI NA PARAMETRE ANTIOKSIDANTNE ZAŠTITE KOD \\ ADOLESCENATA SA POVEĆANIM KARDIOVASKULARNIM RIZIKOM \\ Emina Čolak¹, Dragana Pap², Ljubinka Nikolić3, Sanja Vicković4 \\ ${ }^{1}$ Institute of Medical Biochemistry, Clinical Center of Serbia and School of Pharmacy, University of Belgrade \\ ${ }^{2}$ Institute for the Health Protection of Students, Department of Laboratory Diagnostics, Novi Sad \\ ${ }^{3}$ Clinic for Gynecology and Obstetrics, Department for Hematology and Transfusion Laboratory, \\ Clinical Center of Serbia \\ ${ }^{4}$ Department of Anesthesiology and Intensive Care, Clinical Center of Vojvodina and School of Medicine, \\ University of Novi Sad, Serbia
}

\begin{abstract}
Summary
Background: The goal of this study was to assess the oxidative stress status through the values of antioxidant defense parameters: superoxide dismutase (SOD), glutathione peroxidase (GPx), glutathione reductase (GR) and total antioxidant status (TAS), as well as cardiovascular risk factors (total cholesterol, LDL-cholesterol, VLDL-cholesterol, nonHDL-cholesterol and triglycerides), anthropometric parameters (Body mass index-BMI, waist circumference-WC, hipp circumferemce-HC, waist-to-hipp ratio-WHR and inflammatory markers (high sensitive C-reactive protein) in a group of obese adolescents.

Methods: A total of 238 students of both sexes, age of 22.32 $\pm 1.85 \mathrm{yr}$. were included in the study. According to the values of BMI lower and higher than $25 \mathrm{~kg} / \mathrm{m}^{2}$ and WC higher and lower than $94 \mathrm{~cm}$ (males)/80 cm (females) the tested group of students was divided into 2 subgroups: Group 1 (increased risk for CVD) and Group 2 (lower risk for CVD).

Results: Significantly reduced SOD and GPx with increased GR, TAS, inflammatory and lipoprotein parameters were obtained in Group 1 compared to Group 2. Significant positive association of hsCRP (OR:1.41; 95\%Cl 1.08-1.83; $\mathrm{P}=0.007)$, TAS (OR:827.2; 95\%Cl 19.27-35498; $\mathrm{P}=0.007$ )
\end{abstract}

\section{Kratak sadržaj}

Uvod: Cilj ovog rada je bio da se proceni oksidativni status u grupi gojaznih adolescenata preko vrednosti antioksidantih parametara: superoksid dizmutaze (SOD), glutation peroksidaze $(\mathrm{GPx})$, glutation reduktaze $(\mathrm{GR}) \mathrm{i}$ totalnog antioksidantnog statusa (TAS), kardiovaskulanih faktora rizika (ukupni holesterol, LDL-holesterol, VLDLholesterol, non-HDL-holesterol, i trigliceridi), antropometrijskih parametara (Body mass index-BMI, obim struka, obim kuka i odnos struk/kuk) i inflamatornog markera visoko osetljivog C-reaktivnog proteina (hsCRP).

Metode: U studiju je uključeno 238 studenata,oba pola, starosti od 22,32 $\pm 1,85$ godina. $U$ odnosu na vrednosti BMI većih ili manjih od $25 \mathrm{~kg} / \mathrm{m}^{2}$, i obima struka veće ili manje od $94 \mathrm{~cm}$ (za muškarce) tj. $80 \mathrm{~cm}$ (za žene), celokupna grupa studenata je podeljena na dve podgrupe: Grupa 1 (sa povećanim kardiovaskularnim rizikom) i Grupa 2 (sa sniženim kardiovaskularnim rizikom).

Rezultati: Značajno smanjene vrednosti SOD-a, GPx-a, a povećane vrednosti GR, TAS-a, inflamatornih i lipidnih parametara su dobijene u Grupi $1 \mathrm{u}$ odnosu na Grupu 2 ispitanika. Dobijena je značajna pozitivna asocijacija hsCRPa (OR:1,41; 95\%Cl 1,08-1,83; $\mathrm{P}=0,007)$, TAS-a

Address for correspondence:

Emina Čolak PhD, Research Associate

Department for Scientific Research and Education

Institute of Medical Biochemistry

Clinical Centre of Serbia

Vi egradska Street No.26

11000 Belgrade, Serbia

e-mail: eminacolak@sbb.rs 
and GR (OR:1.13; 95\%Cl 1.05-1.21; $\mathrm{P}=0.002)$ and negative association of GPx (OR:0.97; 95\% Cl 0.94-1.003 $\mathrm{P}=0.043)$ and $\mathrm{HDL}$-cholesterol (OR:0.41; 95\% Cl 0.176$0.963 ; \mathrm{P}=0.0014$ ) with cardiovascular risk factors were found in obese students. According to the ROC analysis $\mathrm{GR}>44.8 \mathrm{U} / \mathrm{L}, \mathrm{TAS}>1.35 \mathrm{mmol} / \mathrm{L}$, hsCRP>1.71 mg/L and HDL-cholesterol $<1.13 \mathrm{mmol} / \mathrm{L}$ have sufficient predictive ability for cardiovascular disease in obese students. Conclusions: Significant association of antioxidant defense parameters with anthropometric, lipid and inflammatory markers in obese students with increased cardiovascular risk suggest that screening of these parameters is necessary and highly recommended.

Keywords: obesity, oxidative stress, antioxidant defense, cardiovascular risk factors, inflammation

\section{Introduction}

Obesity is defined as a serious nutrition problem, resulting from excessive accumulation of fat. It is documented that abdominal fat is recognized as the major risk factor for obesity related diseases such as: hypertension, dyslipidemia, diabetes mellitus type 2, coronary heart disease, non-alcoholic fatty liver disease, stroke etc. Fat accumulation is associated with increased pro-oxidant and pro-inflammatory states. Recent published studies suggest that oxidative stress could be the link between obesity and related complications $(1,2)$.

Nowadays, obesity becomes the main cause of diabetes and related diseases. In obese patients occur metabolic changes such as dyslipidemia, insulin resistance, diabetes, fatty-inflammatory degeneration of the liver (non-alcoholic fatty liver disease), kidney and heart failure, cardiomyopathy etc. $(3,4)$.

Impairment of glucose concentration and insulin function are the cause of the metabolic abnormalities found in obesity. Most recent studies confirm that the $\mathrm{BMI}$ values continue to increase all over the world (5). The reason for this is economic growth and changes in nutrition patterns in combination with available, cheap and unbalanced food, rich in carbohydrates and fat. Excess food intake is usually followed by a sedentary lifestyle, lack of physical activity and increased consumption of high caloric food, nonalcoholic and alcoholic drinks (6).

There are evidences that obesity increasingly affects school children who at young age develop arterial hypertension, cardiovascular disease and diabetes mellitus. Overweight children develop abnormal vascular wall (7). A recent paper of Niemann et al. concluded that obesity induces premature cardiac aging in young patients (8). Increased oxidative stress in adipocites is important pathogenic mechanism of metabolic syndrome (9).

It is thought that oxidative stress could be a consequence, but also a trigger of obesity. Increase intake of fats, carbohydrates and saturated fatty acids,
(OR:827,2; 95\%Cl 19,27-35498; $\mathrm{P}=0.007) \mathrm{GR}(\mathrm{OR}: 1,13$; $95 \% \mathrm{Cl} 1,05-1,21 ; \mathrm{P}=0,002)$ i negativna asocijacija $\mathrm{GPx}-\mathrm{a}$ (OR:0,97; 95\% Cl 0,94-1,003; P=0,043) i HDL-holesterola (OR:0,41; 95\% Cl 0,176-0,963; $\mathrm{P}=0,0014$ ) sa kardiovaskularnim faktorima rizika u grupi gojaznih studenata. ROC analiza je pokazala da su $\mathrm{GR}>44,8 \mathrm{U} / \mathrm{L}, \mathrm{TAS}>1,35 \mathrm{mmol} / \mathrm{L}$, hsCRP>1,71 mg/L i HDL-holesterol < 1,13 mmol/L dovoljno snažni prediktori kardiovaskularnih bolesti kod gojaznih studenata.

Zaključak: Značajna asocijacija antioksidantnih parametara sa antropometrijskim, lipidnim i inflamatornim markerima u gojaznih studenata ukazuje na to da je skrining ovih parametara neophodan i preporučljiv.

Ključne reči: gojaznost, oksidativni stres, antioksidantna zaštita, kardiovaskularni faktori rizika, inflamacija

especially trans-fatty acids lead to increase oxidative stress. The multiple biochemical mechanisms responsible for increased oxidative stress include several processes such as: the superoxide generation via the activity of NADPH oxidase, oxidative phosphorilation, glyceraldehyde auto-oxidation, protein kinase $\mathrm{C}$ (PKC) activation, polyol and hexosamine pathways (10). On the other hand, oxidative stress plays a causative role in development of obesity by stimulating the deposition of adipose tissue including preadipocite proliferation, adipocite differentiation and growth (11).

Adipose tissue, as an endocrine and energy storage organ, secretes hormones and cytokines (adipokines) which manifest endocrine, paracrine and autocrine action. Adipokines could induce the production of reactive oxygen species. It was documented that oxidative stress is strongly related to inflammatory processes in obesity. Adipose tissue secretes pro-inflammatory citokines such as: tumor-necrosis factor $\alpha$ (TNF- $\alpha$ ), interleukin $1 \beta$ (IL-1 $\beta$ ) and IL-6 (12).

The goal of this study was to analyze the oxidative stress status of obese students with and without increased risk for cardiovascular events (CVD) through the values of antioxidant parameters: superoxide dismutase (SOD), glutathione peroxidase $(G P x)$, glutathione reductase $(G R)$ and total antioxidant status (TAS). In addition, the aim was to determine the correlation of tested antioxidant parameters with the cardiovascular risk parameters: total cholesterol, LDL-cholesterol, VLDL-cholesterol, nonHDLcholesterol, triglycerides, high sensitive CRP (hsCRP) and anthropometric parameters as well as: body mass index (BMI), waist circumference (WC), hipp circumference $(H C)$ and waist-to hip ratio (WHR) and to determine the minimum concentration of tested parameters (the cutoff points) that could be associated with cardiovascular risk. 


\section{Materials and Methods}

The cross-sectional study, conducted at the Institute for the Health Protection of Students, University of Novi Sad, included a total of 238 students, of both sexes (126 males and 112 females), aged of 18 to $29 \mathrm{yr}$. (22.32 \pm 1.85$)$. They were recruited from a regular medical checkup, from April 2012 to April 2014. Out of total number of tested students, 164 were obese or overweight $(\mathrm{BMl}>25$ $\mathrm{kg} / \mathrm{m}^{2}$ and $W C>94 \mathrm{~cm}$ for men, or $W C>80 \mathrm{~cm}$ for women). They comprised the group with increased risk for CVD (Group 1). The remaining 74 students, having $B M I<25 \mathrm{~kg} / \mathrm{m}^{2}$ and $W C<94 \mathrm{~cm} /<80 \mathrm{~cm}$ for females comprised the control group (Group 2). The blood samples for analysis were taken after 12-14 hours of overnight fast and following parameters were analysed: glucose, lipid levels, superoxide dismutase (SOD), Se-dependent glutathione peroxidase (GPx), glutathione reductase (GR), total antioxidant status (TAS) and hsCRP as well. All tested antioxidant parameters were determined by commercial tests Randox Ltd. UK, based on spectrophotometric methods.

SOD was determined by a method developed by Goldstein (13) in blood hemolysate, obtained by washing of erythrocytes with $154 \mathrm{mmol} / \mathrm{L}$ of $\mathrm{NaCl}$. Finally, the aliquots of washed erythrocytes were lysed with cold deionized water and put in a cool place (+ $4{ }^{\circ} \mathrm{C}$ ) for 15 minutes in order to complete hemolysis. Glutathione peroxidase (GPx) was determined by the method of Paglia and Valentine (14). According to Miller et al. (15), method for total antioxidant status (TAS) determination included the addition of ABTS ${ }^{\circledR}$ (2,2'-Azino-di-[3-ethylbenzthiazoline sulphonate)) which helps the visualization of stable blue-green colour, while glutathione reductase (GR) was determined by the method of Goldberg (16). TAS and GR were determined in plasma, obtained by centrifugation of the Li-heparinized blood during 10 minutes on $3000 \mathrm{rpm}$. CRP was determined by using an immunochemical high sensitive (hsCRP) method on Olympus AU 400 analyzer.

The lipid parameters (total cholesterol, HDLcholesterol and triglycerides) were assayed by standard laboratory methods on Olympus AU 400 analyzer. HDL-cholesterol was assayed by a direct quantitative method for sin vitro" determination (on Olympus AU400) using colorimetric, end-point immunoinhibition reaction. VLDL-cholesterol was calculated mathematically using the formula: Triglycerides/2.2. LDLcholesterol was calculated by Friedewald formula. Non-HDL-cholesterol values were obtained mathematically by subtracting HDL-cholesterol from total cholesterol values.

All subjects gave their informed consent to participate in this study which was approved by the local Ethics Committee. For statistical evaluation, the Med Calc statistical package v.9.4.2.0 was used with fol- lowed statistical methods: Student's t-test, MannWhitney $U$ test, Chi-Square, and Fisher's exact test. For normally distributed data, results were presented as mean \pm standard deviation (SD), while median and interquartile range was used to present the nonnormally distributed data. Spearman's rank and Pearson's correlation test were used to define correlations of the individual parameters between and within the tested groups. All statistical tests were two-tailed and $P$ values 0.05 were considered statistically significant. Logistic regression analysis was used to determine the association of anthropometric with antioxidant and lipoprotein parameters. The diagnostic sensitivity and specificity of the tests and cutoff values associated with cardiovascular risk were calculated by Receiver operating characteristic (ROC) curve. The goal was to determine the cutoff values where area under the curve (AUC) would be higher than 0.5 , while sensitivity and/or specificity would be at least $70 \%$.

\section{Results}

Significantly lower SOD $(p=0.003)$ and GPx $(p=0.03)$, higher GR $(p=0.0001)$, TAS $(p<0.000)$ values and lipid parameters: total cholesterol LDLcholesterol, non-HDL-cholesterol, VLDL-cholesterol, and triglycerides $(p<0.000)$ were obtained in obese adolescents with increased cardiovascular risk compared to the controls (Table I). Significantly lower values of HDL-cholesterol were obtained in the risk group compared to the control group $(p=0.001)$.

High sensitive $\mathrm{C}$-reactive protein was significantly increased in the Group 1 compared to Group 2 $(p=0.005)$.

A series of interesting correlations were obtained between the tested biochemical and anthropometric parameters. The anthropometric parameters correlated significantly with antioxidant markers in the whole group of examined students. BMI correlated significantly with GR $(p<0.001)$ and TAS $(p<0.001)$. A negative and weak correlation was obtained between SOD and HC $(p=0.014), G P x$ and WHR $(p=0.006)$ and between GPx and WC $(p=0.02)$. GR and TAS correlated positively with all tested anthropometric parameters (BMI, WC, HC and WHR) $(\mathrm{P}<0.001)$ (Table II).

Serum hsCRP concentration increased significantly with increased BMI $(p=0.000), \mathrm{HC}(p=0.000)$, WC $(p=0.000)$ and with WHR $(p=0.002)$ (Table II).

The tested antioxidant parameters GR and TAS correlated positively with lipid parameters: total cholesterol, LDL-cholesterol, non-HDL-cholesterol, VLDLcholesterol and triglycerides $(\mathrm{P}<0.05)($ Table III). Interestingly, HDL-cholesterol negatively correlated with anthropometric parameters: BMI $(p<0.001), H C$ $(p=0.007)$, WC $(p<0.001)$ and WHR $(p<0.001)$. 
Table I Biochemical and anthropometric parameter values in tested subjects.

\begin{tabular}{|c|c|c|c|}
\hline Parameters & $\begin{array}{c}\text { Group } 1 \\
\text { (Increased risk) } \\
\mathrm{N}=164\end{array}$ & $\begin{array}{c}\text { Group } 2 \\
\text { (Control Group) } \\
\mathrm{N}=74\end{array}$ & $\begin{array}{c}\mathrm{P} \\
\text { (significance of difference) }\end{array}$ \\
\hline Age $(y)^{a}$ & $22.82 \pm 1.74$ & $21.99 \pm 2.10$ & $<0.001^{c}$ \\
\hline BMI $\left(\mathrm{kg} / \mathrm{m}^{2}\right)^{a}$ & $28.78 \pm 3.89$ & $20.60 \pm 2.04$ & $<0.001^{c}$ \\
\hline $\mathrm{WC}(\mathrm{cm}) \mathrm{M} / \mathrm{F}^{\mathrm{a}}$ & $97.8 \pm 10.5$ & $73.7 \pm 6.8$ & $<0.001^{c}$ \\
\hline $\mathrm{HC}(\mathrm{cm}) \mathrm{M} / \mathrm{F}^{\mathrm{b}}$ & $115.0(110-120)$ & $98.0(94.8-103)$ & $<0.000^{d}$ \\
\hline WHpR M/F b & $0.85(0.80-0.88)$ & $0.73(0.71-0.78)$ & $<0.000^{d}$ \\
\hline $\mathrm{SOD}(\mathrm{U} / \mathrm{g} \mathrm{Hb})^{a}$ & $1372.6 \pm 185.6$ & $1487.1 \pm 215.3$ & $0.0003^{c}$ \\
\hline$G P x(U / g ~ H b)^{a}$ & $64.8 \pm 10.4$ & $68.86 \pm 13.1$ & $0.032^{c}$ \\
\hline $\mathrm{GR}(\mathrm{U} / \mathrm{L})^{\mathrm{a}}$ & $51.3 \pm 7.2$ & $43.4 \pm 8.7$ & $0.0001^{c}$ \\
\hline TAS (mmol/L) b & $1.42(1.41-1.52)$ & $1.24(1.17-1.37)$ & $<0.000^{d}$ \\
\hline 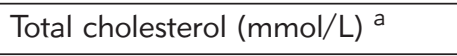 & $5.15 \pm 0.96$ & $4.45 \pm 0.78$ & $<0.0001^{c}$ \\
\hline HDL-cholesterol $(\mathrm{mmol} / \mathrm{L})^{a}$ & $1.23 \pm 0.33$ & $1.42 \pm 0.36$ & $<0.0001^{c}$ \\
\hline 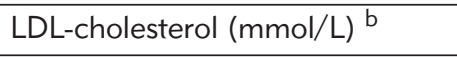 & $3.37(2.72-3.89)$ & $2.54(2.09-3.12)$ & $<0.0001^{d}$ \\
\hline VLDL-cholesterol $(\mathrm{mmol} / \mathrm{L})^{b}$ & $0.49(0.38-0.75)$ & $0.34(0.27-0.43)$ & $<0.0001^{d}$ \\
\hline Non-HDL-cholesterol $(\mathrm{mmol} / \mathrm{L})^{b}$ & $3.91(3.1-4.6)$ & $2.94(2.4-3.4)$ & $<0.0001^{d}$ \\
\hline Triglycerides $(\mathrm{mmol} / \mathrm{L})^{b}$ & $1.07(0.84-1.65)$ & $0.74(0.60-0.95)$ & $<0.0001^{d}$ \\
\hline $\mathrm{hCRP}(\mathrm{mg} / \mathrm{L})^{\mathrm{b}}$ & $2.57(0.93-3.99)$ & $0.56(0.32-1.79)$ & $0.005^{d}$ \\
\hline
\end{tabular}

Legends: ${ }^{a}$ arithmetic mean $\pm \mathrm{SD} ;{ }^{b}$ median and interquartile range; ${ }^{\mathrm{c}}$ Student's t-test; ${ }^{\mathrm{d}}$ Mann-Whitney U-test

Abbreviations: BMI - body mass index; WC - waist circumference; HC - hipp circumference; WHR - waist-to-hipp ratio; SOD - superoxide dismutase; GPx - glutathione peroxidase; GR - glutathione reductase; TAS -total antioxidant status; hCRP - high sensitive Creactive protein

Table II The correlations between biochemical and anthropometric parameters in the group of tested adolescents.

\begin{tabular}{|c|c|c|c|c|}
\hline Parameters & $\mathrm{BMI}$ & $\mathrm{HC}$ & WHR & WC \\
\hline $\mathrm{SOD}(\mathrm{U} / \mathrm{g} \mathrm{Hb})$ & $\begin{array}{c}-0.111 \\
\text { NS }\end{array}$ & $\begin{array}{c}-0.187 \\
0.014\end{array}$ & $\begin{array}{c}0.063 \\
\text { NS }\end{array}$ & $\begin{array}{c}-0.057 \\
\text { NS }\end{array}$ \\
\hline $\mathrm{GPx}(\mathrm{U} / \mathrm{g} \mathrm{Hb})$ & $\begin{array}{c}-0.08 \\
\text { NS }\end{array}$ & $\begin{array}{c}-0.085 \\
\text { NS }\end{array}$ & $\begin{array}{c}-0.208 \\
0.005\end{array}$ & $\begin{array}{c}-0.163 \\
0.028\end{array}$ \\
\hline GR (U/L) & $\begin{array}{c}0.456 \\
<0.0001\end{array}$ & $\begin{array}{c}0.357 \\
0.0013\end{array}$ & $\begin{array}{c}0.465 \\
<0.0001\end{array}$ & $\begin{array}{c}0.450 \\
<0.0001\end{array}$ \\
\hline TAS (mmol/L) & $\begin{array}{c}0.536 \\
<0.0001 \\
\end{array}$ & $\begin{array}{c}0.469 \\
<0.0001 \\
\end{array}$ & $\begin{aligned} & 0.573 \\
< & 0.0001\end{aligned}$ & $\begin{array}{c}0.584 \\
<0.0001\end{array}$ \\
\hline $\mathrm{hsCRP}(\mathrm{mg} / \mathrm{L})$ & $\begin{array}{l}0,393 \\
0.000 \\
\end{array}$ & $\begin{array}{l}0.377 \\
0.000 \\
\end{array}$ & $\begin{array}{l}0.346 \\
0.002 \\
\end{array}$ & $\begin{array}{l}0.385 \\
0.000 \\
\end{array}$ \\
\hline Total cholesterol $(\mathrm{mmol} / \mathrm{L})$ & $\begin{array}{c}0.33 \\
<0.0001\end{array}$ & $\begin{array}{l}0.221 \\
0.000\end{array}$ & $\begin{array}{c}0.244 \\
<0.0001\end{array}$ & $\begin{array}{c}0.272 \\
<0.0001\end{array}$ \\
\hline HDL-cholesterol (mmol/L) & $\begin{array}{l}-0.249 \\
0.0001\end{array}$ & $\begin{array}{l}-0.18 \\
0.006 \\
\end{array}$ & $\begin{array}{c}-0.274 \\
<0.0001\end{array}$ & $\begin{array}{c}-0.267 \\
<0.0001\end{array}$ \\
\hline LDL-cholesterol ( $\mathrm{mmol} / \mathrm{L})$ & $\begin{array}{c}0.275 \\
<0.0001\end{array}$ & $\begin{array}{l}0.174 \\
0.007\end{array}$ & $\begin{array}{l}0.198 \\
0.002\end{array}$ & $\begin{array}{l}0.212 \\
0.001\end{array}$ \\
\hline $\begin{array}{r}\text { Non-HDL-cholesterol (mmol/L) } \rho \\
p\end{array}$ & $\begin{array}{c}0.392 \\
<0.0001\end{array}$ & $\begin{array}{l}0.280 \\
<0.0001\end{array}$ & $\begin{array}{c}0.301 \\
<0.0001\end{array}$ & $\begin{array}{l}0.333 \\
<0.0001\end{array}$ \\
\hline VLDL-cholesterol (mmol/L) & $\begin{aligned} & 0.504 \\
&< 0.0001 \\
&\end{aligned}$ & $\begin{aligned} & 0.437 \\
< & 0.0001\end{aligned}$ & $\begin{aligned} & 0.457 \\
&< 0.0001 \\
&\end{aligned}$ & $\begin{array}{l}0.503 \\
<0.0001\end{array}$ \\
\hline Triglycerides (mmol/L) & $\begin{array}{c}0.51 \\
<0.0001 \\
\end{array}$ & $\begin{aligned} & 0.435 \\
&< 0.0001 \\
&\end{aligned}$ & $\begin{aligned} & 0.467 \\
< & 0.0001\end{aligned}$ & $\begin{array}{c}0.501 \\
<0.0001\end{array}$ \\
\hline
\end{tabular}

Legends: BMI: Body mass index; HC: hip circumference; WC: waist circumference; WHR: waist-to-hip ratio; SOD: Superoxide dismutase; GPx: Glutathione peroxidase; GR: Glutathione reductase; TAS: Total antioxidant status; hsCRP: high sensitive C-reactive protein; $\rho$ : Spearmen's correlation coefficient; p: significance of difference; NS-non significant 
Table III The correlations between biochemical and lipoprotein parameters in the group of obese adolescents.

\begin{tabular}{|c|c|c|c|c|c|}
\hline Parameters & & SOD & GPx & GR & TAS \\
\hline Total cholesterol (mmol/L) & $\begin{array}{l}\rho \\
p\end{array}$ & $\begin{array}{c}-0.003 \\
\text { NS }\end{array}$ & $\begin{array}{c}0.122 \\
\text { NS }\end{array}$ & $\begin{array}{c}0.262 \\
0.02\end{array}$ & $\begin{array}{c}0.239 \\
0.04\end{array}$ \\
\hline HDL-cholesterol (mmol/L) & $\begin{array}{l}\rho \\
p\end{array}$ & $\begin{array}{c}-0.007 \\
\text { NS }\end{array}$ & $\begin{array}{c}0.139 \\
\text { NS }\end{array}$ & $\begin{array}{c}-0.102 \\
\text { NS }\end{array}$ & $\begin{array}{c}-0.201 \\
\text { NS }\end{array}$ \\
\hline LDL-cholesterol (mmol/L) & $\begin{array}{l}\rho \\
p\end{array}$ & $\begin{array}{l}0.025 \\
\text { NS }\end{array}$ & $\begin{array}{c}-0.023 \\
\text { NS }\end{array}$ & $\begin{array}{c}0.246 \\
0.03\end{array}$ & $\begin{array}{l}0.296 \\
0.015\end{array}$ \\
\hline non-HDL-cholesterol (mmol/L) & $\begin{array}{l}\rho \\
p\end{array}$ & $\begin{array}{l}0.018 \\
\text { NS }\end{array}$ & $\begin{array}{l}0.05 \\
\text { NS }\end{array}$ & $\begin{array}{l}0.331 \\
0.003\end{array}$ & $\begin{array}{l}0.295 \\
0.012\end{array}$ \\
\hline VLDL-cholesterol (mmol/L) & $\begin{array}{l}\rho \\
p\end{array}$ & $\begin{array}{c}-0.026 \\
\text { NS }\end{array}$ & $\begin{array}{c}0.096 \\
\text { NS }\end{array}$ & $\begin{array}{l}0.278 \\
0.013\end{array}$ & $\begin{array}{l}0.411 \\
0.003 \\
\end{array}$ \\
\hline Triglycerides $(\mathrm{mmol} / \mathrm{L})$ & $\begin{array}{l}\rho \\
p\end{array}$ & $\begin{array}{c}-0.076 \\
\text { NS }\end{array}$ & $\begin{array}{c}0.093 \\
\text { NS }\end{array}$ & $\begin{array}{l}0.278 \\
0.013\end{array}$ & $\begin{array}{l}0.405 \\
0.000 \\
\end{array}$ \\
\hline $\mathrm{hsCRP}(\mathrm{mg} / \mathrm{L})$ & $\begin{array}{l}\rho \\
p\end{array}$ & $\begin{array}{l}0.04 \\
\text { NS }\end{array}$ & $\begin{array}{c}0.146 \\
\text { NS }\end{array}$ & $\begin{array}{l}0.361 \\
0.006 \\
\end{array}$ & $\begin{array}{c}0.051 \\
\text { NS }\end{array}$ \\
\hline
\end{tabular}

Legends: hsCRP-high senditive C-reactive protein; SOD-superoxide dismutase; GPx-glutathione peroxidase; GR-glutathione peroxidase; TAS-total antioxidant status; $\rho$ (rho)-Spearman's correlation coefficient; $p$-significance of difference; NS-non significant

Table IV Logistic regression analysis: the association of tested parameters with the risk for cardiovascular disease in tested group of students.

\begin{tabular}{|c|c|c|c|c|}
\hline Parameter & OR & $95 \% \mathrm{Cl}$ & $\chi^{2}$ & $P$ \\
\hline hsCRP (mg/L) & 1.41 & $1.08-1.83$ & 21.02 & 0.007 \\
\hline $\mathrm{BMI}\left(\mathrm{kg} / \mathrm{m}^{2}\right)$ & 3.12 & $2.21-4.39$ & 18.1 & 0.02 \\
\hline WC (cm) & 1.44 & $1.29-1.60$ & 12.33 & 0.137 \\
\hline $\mathrm{HC}(\mathrm{cm})$ & 1.91 & $1.55-2.35$ & 5.32 & 0.723 \\
\hline $\mathrm{SOD}(\mathrm{U} / \mathrm{g} \mathrm{Hb})$ & 0.997 & $0.995-0.998$ & 15.36 & 0.052 \\
\hline $\mathrm{GPx}(\mathrm{U} / \mathrm{g} \mathrm{Hb})$ & 0.97 & $0.94-1.003$ & 15.95 & 0.043 \\
\hline $\mathrm{GR}(\mathrm{U} / \mathrm{g} \mathrm{Hb})$ & 1.13 & $1.05-1.21$ & 23.86 & 0.002 \\
\hline TAS (mmol/L) & 827.2 & $19.27-35498$ & 28.70 & 0.0007 \\
\hline Total cholesterol (mmol/L) & 2.31 & $1.64-3.26$ & 12.37 & 0.135 \\
\hline HDL-cholesterol (mmol/L) & 0.41 & $0.176-0.963$ & 22.56 & 0.004 \\
\hline LDL-cholesterol (mmol/L) & 2.41 & $1.67-3.46$ & 9.27 & 0.32 \\
\hline Non-HDL-cholesterol (mmol/L) & 2.65 & $1.86-3.78$ & 12.63 & 0.125 \\
\hline VLDL-cholesterol (mmol/L) & 69.1 & $11.9-401$ & 14.63 & 0.066 \\
\hline Triglycerides (mmol/L) & 6.95 & $3.14-15.39$ & 13.2 & 0.105 \\
\hline
\end{tabular}

Legends: hsCRP-high sensitive C-reactive protein; BMI: Boody mass index; WC: waist circumference; HC: hip circumferemce; SOD: superoxide dismutase; GPx: glutathione peroxidase; GR: glutathione reductase; TAS: Total antioxidant status; OR: Odds ratio; Cl: Confidense interval; P: significance of difference; $\chi^{2}$ : chi square test

Table V ROC analysis for selected parameters.

\begin{tabular}{|l|c|c|c|c|c|c|}
\hline Parameter & AUC & SE & $95 \% \mathrm{Cl}$ & Sensitivity \% & Specificity \% & Cutoff \\
\hline SOD (U/g Hb) & 0.660 & 0.071 & $0.53-0.77$ & 55.6 & 66.7 & 1442 \\
\hline GPx (U/g Hb) & 0.593 & 0.043 & $0.52-0.67$ & 62 & 58.3 & 65 \\
\hline GR (U/L) & 0.839 & 0.053 & $0.73-0.92$ & 81.2 & 76.1 & 44.8 \\
\hline TAS (mmol/L) & 0.797 & 0.052 & $0.68-0.89$ & 92.3 & 67.4 & 1.35 \\
\hline hsCRP (mg/L) & 0.695 & 0.066 & $0.58-0.79$ & 73.3 & 75.0 & 1.71 \\
\hline Total cholesterol (mmol/L) & 0.712 & 0.036 & $0.65-0.77$ & 55.5 & 88.9 & 5.12 \\
\hline HDL-cholesterol (mmol/L) & 0.662 & 0.037 & $0.59-0.72$ & 48.8 & 81.9 & 1.13 \\
\hline LDL-cholesterol (mmol/L) & 0.717 & 0.036 & $0.66-0.77$ & 65.67 & 73.6 & 2.92 \\
\hline VLDL-cholesterol (mmol/L) & 0.751 & 0.035 & $0.69-0.81$ & 72.56 & 69.4 & 0.39 \\
\hline Non-HDL-cholesterol (mmol/L) & 0.754 & 0.034 & $0.69-0.80$ & 66.5 & 79.2 & 3.55 \\
\hline Triglycerides (mmol/L) & 0.753 & 0.034 & $0.69-0.81$ & 72.56 & 69.44 & 0.86 \\
\hline
\end{tabular}

Legends: AUC-area under the curve; SE-standard error; $\mathrm{Cl}$-confidence interval

Abrreviations: SOD - superoxide dismutase; GPx - glutathione peroxidise; GR - glutathione reductase; TAS - total antioxidant status; hCRP - high sensitive C-reactive protein 
Increased concentration of total cholesterol, LDL-, non-HDL-, and VLDL-cholesterol, and triglycerides were found with increased $\mathrm{BMI}, \mathrm{HC}$, WHTR and WC $(P<0.001)$ (Table II).

In the group of obese students with increased cardiovascular risk hsCRP correlated positively with SOD $(r=0.389 ; \quad P=0.049)$ and GPx $(r=0.579$; $\mathrm{P}=0.000)$. In the same group, GPx showed a weak correlation with non-HDL-cholesterol $(r=0.197$; $P=0.04)$, VLDL-cholesterol $(r=0.273 ; P=0.004)$ and triglycerides $(r=0.268 ; P=0.005)$, while TAS correlated positively with LDL-cholesterol $(r=0.455$; $\mathrm{P}=0.019$ ).

Using logistic regression analysis significant positive association was found between increased risk for cardiovascular disease and BMI (OR: 3.12; 95\%Cl 2.21-4.39; $\mathrm{P}=0.02$ ), hsCRP (OR: 1.41; 95\%Cl 1.08-1.83; $P=0.007$ ), TAS (OR: 827.2; $95 \% \mathrm{Cl}$ 19.27-35498; $\mathrm{P}=0.007)$ and $\mathrm{GR}(\mathrm{OR}: 1.13 ; 95 \% \mathrm{Cl}$ 1.05-1.21; $P=0.002$ ) and negative association of increased risk for CVD with GPx (OR: 0.97; 95\%CI 0.94-1.003; $\mathrm{P}=0.043$ ) and HDL-cholesterol (OR: $0.41 ; 95 \% \mathrm{Cl} 0.176-0.963 ; \mathrm{P}=0.0014$ ) (Table IV).

The cutoff points of all tested parameters that could be associated with cardiovascular risk were calculated using ROC analysis (Table V). Taking into account the statistical parameters of the ROC curve (AUC > 0.5 with $95 \% \mathrm{Cl}$, the sensitivity and/or specificity of diagnostic tests $>70 \%$ ) (Table V) and according to the determined cutoff values, we can conclude that only $G R>44.8 \mathrm{U} / \mathrm{L}$, TAS $>1.35 \mathrm{mmol} / \mathrm{L}$, hsCRP $>1.71 \mathrm{mg} / \mathrm{L}$ and $\mathrm{HDL}$-cholesterol $<1.13 \mathrm{mmol} / \mathrm{L}$ have sufficient predictive ability for cardiovascular disease in obese students.

\section{Discussion}

According to the obtained results, it can be concluded that the cardiovascular risk factors, primarily increased BMI, waist circumference, lipids (total cholesterol, LDL-cholesterol, VLDL-cholesterol, nonHDL-cholesterol, triglycerides) and inflammatory markers (hsCRP) were significantly increased in the Group 1 of University students compared to the control group $(p<0.001)$. Numerous previous studies have shown undoubted correlation between coronary heart disease and serum lipid levels. The examination in our region, have also showed that hyperlipoproteinemia was among the most common risk factors for cardiovascular disease (17). The analysis of cholesterol fractions and triglycerides in the students' examined groups showed that all parameters were within the reference range values, but values in the risk group were significantly increased compared to the control group (Table I). Increased indicators of obesity (BMI and WC) in the risk group pose a risk for CVD through increased parameters of lipid status, especially WC as a cardiometabolic risk factor which has been confirmed by many studies and researches $(18,19)$.

It is interesting to note that some antioxidant parameters (SOD and GPX) were significantly decreased, while GR and TAS were significantly increased in the group of students with increased cardiovascular risk compared to the controls $(p<0.01)$ although absolute values were within the reference range. CRP levels were significantly higher while HDL-cholesterol levels were significantly lower in the high-risk group compared to the control group ( $p=$ 0.006 and $p<0.0001$ respectively). Our results are in accordance with data reported in literature suggesting that patients with elevated waist circumference have increased oxidative stress biomarkers. Considering the association between obesity and lipid status, our finding points to the complex link between the balance of redox status and lipid profiles in young people evidenced by the study of Barbosa et al. (20). This author points to a positive correlation between the activity of glutathione peroxidase with ox-LDLcholesterol and other lipid biomarkers. This is probably part of the antioxidant protective mechanism as some authors had shown, suggesting that increased activity of GPx can reduce the risk of cardiovascular disease while low levels of GPx can be used as independent predictor for increased risk in patients with coronary artery disease $(21,22)$. Therefore, GPx may have prognostic significance along with other traditional cardiovascular risk factors. Our study showed that the most sensitive predictor for CVD in obese students was TAS. Subjects with higher TAS values than established cutoff values $(1.35 \mathrm{mmol} / \mathrm{L})$ were on average 800 times (827.2) more likely to develop cardiovascular complications compared to those students with lower TAS values. The second powerful predictor for cardiovascular events in our study was hsCRP with satisfactory sensitivity $(73.3 \%)$ and specificity (75\%). Obese subjects with hsCRP serum levels over $1.71 \mathrm{mg} / \mathrm{L}$ have almost 2 times higher probability to develop some cardiovascular events.

Recent publications of Nikolaidis (23) and Gutierez-Lopez (24) pointed out to altered antioxidant defense in obese people although relationship between BMI, body fat and antioxidant defense was still an open question.

The evidence of impaired obesity-related antioxidant system arises from several observational, clinical and in vitro studies. In a population-based study, Chrysohoou et al. (25) have documented an inverse relationship between visceral fat and total antioxidant capacity (TAC). This correlation was stronger for waist circumference with respect of BMI (25). According to Mittal (26) and Olivares-Corichi (27), SOD, catalase and GPx activities were inversely related to BMI both in obese children and adults. Similar correlations were found in our study: SOD correlated negatively with HC $(p=0.014)$ while GPx correlated inversely with WC and WHR $(p<0.05)($ Table II). Bougoulia et 
al. (28) reported significant increasing activity of GPx in obese women after weight reduction. Opposite to these findings, some researchers reported that severely obese patients with greater insulin resistance have greater GPx activity than control counterparts (29). Tabour et al. (30) demonstrated that obese patients and patients with metabolic syndrome had significantly lower TAS and higher CRP values compared to the controls $(P<0.05)$. In that study, BMI showed a positive correlation with CRP and negative correlation with TAS. TAS correlated negatively with WC, triglycerides levels and systolic and diastolic blood pressures $(P<0.001)$. Chrysohoou et al. (25) reported that central adiposity correlates with decreased antioxidant capacity irrespective of age, metabolic and various lifestyle variables in adults. Both Olusi et al. (31) and Ozata et al. (32) found that SOD and CPx activities were lower in obese persons as compared to non-obese individuals.

Increased cardiac lipid accumulation and altered substrate metabolism can cause cardiovascular complication in obese people. It has been documented that adipokines such as leptin, adiponectin, resistin and fatty acid binding protein 4 (FABP4) can affect cardiac structure and function in obese subjects (33).

Increased leptin concentrations are well associated with obesity and triglyceride storage. It was also documented that leptin promotes oxidative stress by increasing phagocytic activity of macrophages, inducing synthesis of pro-inflammatory cytokine (TNF- $\alpha$, IL-6, IL-2) and interferon gamma (IFN- $\gamma$ ) and increases the levels of endothelial cell dysfunction and level of activation markers. It was hypothesized that proinflammatory effects of leptin were related to structural and functional similarities with the IL- 6 family of cytokines (34).

Contributing to higher LDL-cholesterol and lower HDL-cholesterol levels, adiponectin which plays a central role in obesity-related metabolic disorders can lead to cardiac failure (35). It has been documented that adiponectin inversely correlates with $\mathrm{BMI}$ and directly with TNF- $\alpha$, IL-6 and CRP (36). Increased CRP and reactive oxygen species (ROS) could trigger endothelial dysfunction that can increase the levels of ICAM-1 and VCAM-1, leading to increased monocyte chemoattraction, binding to LDL-molecules and increased risk for cardiovascular disease (37). Metabolic disorders in obesity can disturb the oxidant-antioxidant balance which can also lead to cardiac stress. Obesity is associated with changes in antioxidant enzymes activities, altering the binding to their receptors and modifying protein functioning and their immunogenic properties. Increased oxidative stress and hyperglycemia result in accumulation of advanced glycation end products (AGE) which can cause cellular damage by inducing cross- linking of proteins and collagen and promoting alteration of extracellular matrix and vascular function and structure $(38,39)$.

In a clinical study conducted by Bigornia et al. (40) it has been proved that long-term weight reduction can improve cardiovascular risk by decreasing oxidative stress markers and by increasing antioxidant defense system. Diet regimen containing fruits, green vegetables, whole grains, fish and olive oil rich in monounsaturated fatty acids and ' $\Omega-3$ polyunsaturated fatty acids, vitamin $C$ and $E$ can reduce the weight and decrease the risk for metabolic disorders through mechanisms of cell signaling, gene-expression, decreased oxidative stress, inflammation and lipid accumulation (35).

Exercise-induced weight loss could improve the whole body redox state by modulating both oxidative stress and antioxidant biomarkers, ameliorating endothelial dysfunction and inflammation (41).

According to our results, it is obvious that obesity is strictly linked to changes in redox state. Significant association of antioxidant defense parameters with anthropometric, lipid and inflammatory markers in obese students with increased cardiovascular risk suggest that screening of these parameters is necessary and highly recommended in young adolescents especially in those with a family history of diabetes and cardiovascular disorders. It should be noted that so far, antioxidant markers have not been introduced into routine laboratory practice but are used exclusively for scientific and research purposes. The determination methods used in this study were successfully applied on Olympus AU400 analyzer which significantly shortened the determination time, reduced the reagent consumption, and increased the accuracy and precision of determination both in and between series. Therefore, methods are no longer as complicated and time-consuming as when determination is done manually. Given that most of the biochemical laboratories are today automated, each laboratory can apply these tests to the existing appliances. Introduction of these methods into daily laboratory practice would help and will allow that determination of these parameters become included into mandatory screening of obese individuals and those with increased risk for CVD. This would help such individuals to timely undergo to an adequate diet and treatment regimen which would significantly reduce morbidity and subsequent mortality from cardiovascular disease.

\section{Conflict of interest statement}

The authors state that they have no conflicts of interest regarding the publication of this article. 


\section{References}

1. Perović Blagojević I, Ignjatović S, Macut Dj, Kotur-Stevuljević J, Božić-Antić I, Vekić J, Bjekić-Macut J, Kastratović-Kotlica B, Andrić Z, Ilić D. Evaluation of a summary score for dyslipidemia, oxidative stress and inflammation (the doi score) in 11 women with polycystic ovary syndrome and its relationship with obesity. J Med Biochem 2018; 37: 476-85.

2. Ates E, Set T, Karahan CS, Bicer C, Erel Ö. Thiol/disulphide homeostasis, ischemia modified albumin and peroxidase as oxidative stress markers in women with obesity with insulin resistance. J Med Biochem 2019; 38: $445-51$.

3. Barton M, Baretella O, Meyer MR. Obesity and risk of vascular disease: importance of endothelium-dependent vasoconstriction. British J Pharmacol 2012; 165: 591602.

4. Čolak E, Pap D, Majkić-Singh N, Obradović I. The association of obesity and liver enzymes activities in a student population at increased risk for cardiovascular disease. J Med Biochem 2013; 32: 26-31.

5. Nasser HA, Ezz NZA, Abdel-Mageed HM, Ali Radwan R. Body mass index and Creactive protein are potential predictors of asthma development in egyptian polycystic ovary syndrome patients. J Med Biochem 2019; 38: 427-36.

6. Finucane MM, Stevens GA, Cowan MJ, Danaei G, Liu JK, Paciorek CJ et al. Global Burden of Metabolic Risk factors of Chronic Disease Colaborating Group (Body Mass Index). National, regional and global trends in body-mass index since 1980: systematic analysis of health examination surveys and epidemiological studies with 960 country-years and 9.1 million participants. Lancet 2011; 377: 557-67.

7. De Jonge Li, van Osch-Gevers L, Willensen SP, Steergers EA, Hofman A, Helbing WA et al. Growth, obesity and cardiac structures in early childhood: the generation $\mathrm{R}$ study. Hypertension 2011; 57: 934-40.

8. Niemann B, Chen Y, Teschner M, Li L, Sveber RE, Rohrbach S. Obesity induces signs of preamture cardiac aging in younger patients: the role of mitochondria. J Am Coll Cardiol 2011; 57: 577-85.

9. Furukawa S, Fujita T, Shimabukuro M, Iwaki M, Yamada $Y$, Nakajima $Y$ et al. Increased oxidative stress in obesity and its impact on metabolic syndrome. J Clin Invest 2004; 114(12): 1752-61.

10. Winter Y, Sankowski R, Back T. Genetic determinants of obesity and related vascular diseases. Vitam Horm 2013; 91: 29-48.

11. Higuchi M, Dusting GJ, Peshavariva H, Jiang F, Hsiao ST, Chan EC, Liu GS. Differentiation of human adiposederived steam cells into fat involves reactive oxygen species and forkhead box 01 mediated upregulation of antioxidant enzymes. Stem cells Dev 2013; 22: 878-88.

12. Savini I, Catani MV, Evangelista D, Gasperi V, Avigliano L. Obesity-associated oxidative stres: Strategies finalized to improve redox state. Int J Mol Sci 2013,14: 10497-538.

13. Goldstein S, Michel C, Boors A, Saran M, Czapsky G. A critical re-evaluation of some assay methods for super- oxide dismutase activity. Free Radical Biol Med 1988; 4: 295-303.

14. Paglia DE, Valentine WN. Studies on the quantitative and qualitative characterization of glutathione peroxidase. J Lab Clin Med 1967; 70: 158-63.

15. Miller NJ, Rice-Evans C, Davies MJ, Gopinathan V, Milner A. A novel method for measuring antioxidant capacity and its application to monitoring the antioxidant status in premature neonates. Clin Sci 1993; 84: 407-12.

16. Goldberg DM, Spooner RJ. In Bergmeyer HU, editor. Methods of enzymatic analysis. 3rd ed. New York: academic Press 1974, Vol 3, p. 258-65.

17. Mirosavljev M, Mirilov M, Bojanović B, Novaković B. The lipoprotein status in persons with borderline glucose tolerance impairment before and after a reducing diet. Med Pregl 1991; 44 (11-12): 462-6.

18. Pap D, Čolak E, Majkić Singh N, Grubor-Lajšić G, Vicković S. Lipoproteins and other risk factors for cardiovascular disease in a student population. J Med Biochem 2013; 32(2): 140-5.

19. Willdeman RP, Gu D, Reynol ds K, Duan X, Wu X, He J. Are waist circumference and body mass index independently associated with cardiovascular disease risk in Chinese adults? Am J Clin Nutr 2005; 82(6): 1195-202.

20. Barbosa KBF, Volp AC, Hermsdorff HH, Navarro-Blasco I, Angeles Zulet M, Martinez JA, Bressan J. Relationship of oxidized low density lipoprotein with lipid profile and oxidative stress markers in healthy young adults: a translational study. Lipids Health Dis 2011; 10: 61.

21. Blankenberg S, Rupprecht HJ, Bickel C, Torzewski M, Hafner $G$, Tiret $L$, et al. Glutathione peroxidase 1 activity and cardiovascular events in patients with coronary artery disease. N Engl J Med 2003; 349(17): 1605-13.

22. Cheraghi $M$, Ahmadvand $H$, Maleki A, Babaeenezhad E, Shakiba S, Hassanzadeh F. Oxidative Stress Status and Liver Markers in Coronary Heart Disease. Rep Biochem Mol Biol 2019; 8(1): 49-55.

23. Nikolaidis MG, Kerksick CM, Lamprecht M, McAnulty SR. Redox biology of exercise. Oxid Med Cell Longev 2012; 2012: 407978. doi: 10.1155/2012/407978

24. Gutierez-Lopez L, Garcia-Sanchez JR, Rincon-Viquez MJ, Lara-Padilla E, Sierra-Vargas MP, Olivares-Corichi IM. Hypocaloric diet and regular moderate aerobic exercise is an effective strategy to reduce anthrpometric parameters And oxidative stress in obese patients. Obes Facts 2012; 5: 12-22.

25. Chrysohoou C, Panagiotakos DB, Pitsavos C, Skoumas I, Papademetriou L, Economou M, Stefanadis C. The implication of obesity on total antioxidant capacity in apparently healthy men and women. The ATTICA study. Nutr Metab Cardiovasc Dis 2007; 17: 590-7.

26. Mittal PC, Kant R. Correlation of increased oxidative stress to ody weight in disease-free post menopausal women. Clin Biochem 2009; 42: 1007-11.

27. Olivares-Corichi IM, Visquez MJ, Gutierez-Lopez L, Ceballos-Reyes GM, Garcia-Sanchez JR. Oxidative stress present in the blood from obese patients modifies the 
structure and function of insulin. Horm Metab Res 2011; 43: 748-53.

28. Bougoulia M, Triantos A, Kiloakos G. Plasma interleukin6 levels, glutatjione peroxidase and isoprostane in obese women before and after weight loss. Association with cardiovascular risk factors. Hormones 2006; 5: 192-9.

29. Tinahones FJ, Murri-Pierri M, Garrido-Sanchez L, GarciaAlmeida JM, Garcia-Serrano S, Garcia-Arnes J, GarciaFuentes E. Oxidative stress in severly obese persons is greater in those with insulin resistance. Obesity 2009; 17: 240-6.

30. Tabour S, Torun AN, Sabuncu T, Turan MN, Celik H, Ocak AR, Aksoy N. Non-diabetic metabolic syndrome and obesity do not affect serum paroxonase and aryesterase activities but do affect oxidative stress and inflammation. Eur J Endocrinol 2010; 162: 535-41.

31. Olusi SO. Obesity is an independent risk factor for plasma lipid peroxidation and depletion of erythrocyte cytoprotectic enzymes in humans. Int J Obes Relat Metab Disord 2002; 26: 1159-64.

32. Ozata M, Mergen M, Oktenil C, Aydin A, Sanisoglu SY, Bolu $E$, et al. Incresed oxidative stress and hypozincemia in male obesity. Clin Biochem 2002; 35: 627-31.

33. Rani V, Deep G, Singh RK, Palle K, Yadaw UC. Oxidative stress and metabolic disorders: Pathogenesis and therapeutic strategies. Life Sciences 2016; 148: 183-93.

34. Hukshorn CJ, Lindeman JH, Toet KH, Saris WH, Eilers $\mathrm{PH}$, Westerterp-Plantenga MS, Kooistra T. Leptin and the proinflammatory state associated with obesity. J Clin Endocrinol Metab 2004; 89: 1773-8.

35. Ceriello A, Testa R, Genovese S. Clinical implications of oxidative stress and potential role of natural antioxidants in diabetic vascular complications. Nutr Metab Cardiovasc $D$ is 2016; 26(4): 285-92.

36. Shibata R, Ouchi N, Murohara T. Adiponectin and cardiovascular disease. Circ J 2009; 73: 608-14.

37. Tabatabaei-Malazy O, Fakhrzadeh $H$, Sharifi F, Mirarefin M, Arzaghi SM, Badamchizadeh Z, et al. Effect of metabolic control on oxidative stress, subclinical atherosclerosis and peripheral artery disease in diabetic patients. J Diabetes Metab Disord. 2015 Nov 10; 14: 84. doi: 10.1186/s40200-015-0215-5

38. Sonoda N, Inoguchi T. Role of oxidative stress in pathogenesis of diabetic complications. Nihon Rinsho 2012; 70(Suppl 5): 231-5.

39. Čolak E, Majkić-Singh N. The effect of hyperglycemia and oxidative stress on the development and progression of vascular complications in type 2 diabetes. J Med Biochem 2009; 28(2): 63-71.

40. Bigornia MM, Mott DT, Hess CM, Apovian ME, McDonnell MA, Kluge AJ et al. Long-term successful weight loss improves vascular endothelial function in severely obese individuals. Obesity 2010; 18: 754-9.

41. Lobato NS, Filqueira FP, Akamine EH, Tostes RC, Carvalho MHC, Fortes ZB. Mechanisms of endothelial dysfunction in obesity-associated hypertension. Braz J Med Biol Res 2012; 45(5): 392-400. 